\title{
丹下健三による今治市における市民広場の空間構成の変容 THE TRANSFORMATION OF THE SPATIAL COMPOSITION ABOUT THE CIVIC PLAZA IN IMABARI CITY BY KENZO TANGE
}

\author{
千代 章一郎*, 関 谷 航**
}

Shoichiro SENDAI and Wataru SEKIYA

\begin{abstract}
This paper aims to elucidate the transformation of the spatial composition of the civic plaza in Imabari city by Kenzo Tange through the analysis of the extension design process of the Imabari city complex. After the completion of the municipal buildings in Imabari city in 1958, the citizen hall (1965) , the first annex (1972) and the second annex (1994) were also built by Kenzo Tange in the civic plaza as the extension projects. Through the analysis of the construction process of each project, we can find that Kenzo Tange has changed his idea about the civic plaza as the center of the city.
\end{abstract}

\section{Keywords : Tange Kenzo, Civic Plaza, City Hall in Imabari} 丹下健三, 市民広場, 今治市庁舎

\section{1. はじめに}

第二次世界大戦後、日本の民主主義の象徴として全国各地に市民 広場注1) が建設される。その後のモータリゼーションの飛躍的発展 によって、多くの市民広場は機能不全に陥ることになるが、被災し た伝統的都市構造の復興の中で新しく位置づけられた市民広場の都 市空間としての再評価は不十分である ${ }^{\left.\text {ì }_{2}\right)}$ 。

前稿注3) では、丹下健三（1913～2005）の設計による今治市にお ける市民広場（1958）について、市庁舎（1958）、公会堂（1958） における計画案の変遷を分析し、今治市における市民広場の空間構 成を考察した。

今治市の市民広場には、さらに丹下健三の設計により附属建築群 が増築されている。そこで、本稿ではこれらの建築群、すなわち市 民会館（1965）、第 1 別館（1972）、第 2 別館（1994）の増築過程 を分析することによって、丹下健三による市民広場の空間構成手法 の変容について考察することを目的とする。

そこで本稿では、市民広場内に増築された建築群に関する丹下健 三の計画案及び実現した様子について明らかにするために、丹下健


録注7)、今治市議会により増築する建築の計画を行うために設立され た建設委員会による議論を記録した議事録注8) 注9）注10)、今治市の保 存寸る施工図注11）注 12 ）注13)、丹下健三と今治市による会議の様子を 取材し市民に伝えた地方新聞注14）を資料として用いる。また市民広 場の利用の実態を明らかにするために、今治市が発行する郷土誌注 15）注16）及び広報誌注17）を用いる。
そして、1958 年の市庁舎と公会堂による市民広場の空間構成に ついて要約した上で (第 2 章)、増築された建築群について丹下 健三の計画案と施工計画を今治市による整備実態とあわせて分析 し(第 3 章, 第 4 章)、丹下健三による今治市の市民広場における 空間構成の変容を考察する（第 5 章）。

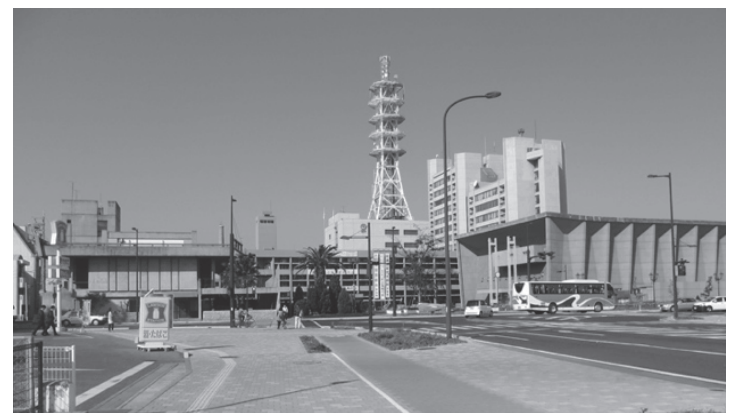

図 1 左より市民会館（1965）、市庁舎（1958）、市民広場（1958） 第 1 別館（1965）、第 2 別館（1994）、公会堂（1958）注18）

\section{2. 市庁舎と公会堂の建設（1958）（表 4 左）}

今治市における市民広場は、丹下健三の提案により今治市庁舎 及び公会堂の新築に伴い実現した。市庁舎の建設予定地は、今治 市の市議会と建設委員会により決定され、城下町を基盤として発 展した旧市街とその外縁で発達した新市街とのおよそ境界となる 地点となった（図 2)。また敷地は、旧市街と新市街を結ぶ十字の 主要道の交点にも位置している。その敷地に市庁舎、公会堂の建
* 広島大学大学院工学研究院 准教授 $\cdot$ 博士 (工学)

** 広島大学大学院工学研究科 修士(工学)
Assoc. Prof., Graduate School of Engineering, Hiroshima Univ., Dr.Eng. Grad. Stud., Graduate School, Hiroshima Univ., M.Eng. 
設を依頼された丹下健三は同時に市民広場の建設を提案した。

最終的に丹下健三は、敷地前面を通る主要道の延長線上に市民広 場の舗装を施し、市庁舎の屋上には旧市街と新市街を見渡すことが できる望楼を配置することで主要道を軸線として取り入れ、市民広 場に旧市街との関連性をもたせる（図 3)。

同時に丹下健三は、公会堂というモニュメントを中心とした「廣 場」を駅や港につながる広小路の前面の道路を含めた空間の拡がり としても捉えている注19)。
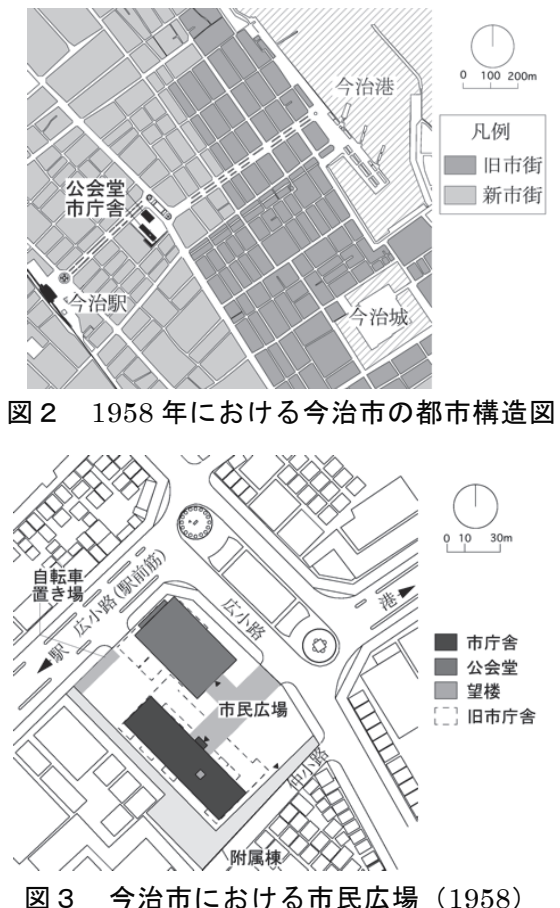

\section{3. 市民会館の増築（1959-1970）（表 1）（表 4）}

3.1. 今治市による計画案（1964 年 1 月 28 日〜1964 年 7 月 25 日）

今治市は、市民から中小規模の集会施設の要望が出たことから、 1964 年 1 月 28 日の会議にて市民会館の建設を決定する注20）。同日、 今治市議会は市民会館の建設計画を行うための建設委員会を設立し 注21)、建設委員会は 1964 年 7 月 25 日に計画案を作成し、市民会館 の規模や具体的な平面計画、各室の面積、建設予定地、予算につい てまとめている注 22 ）

建設委員会は、市民会館の規模を延べ床面積 530 坪とし、地上 4 階と 10 台分の駐車場を整備した半地下を設けることを計画する。 そして、建設予定地には、市民広場内の東隅を選出している。建設 地の選定理由について建設委員会は、市民の利便性が良い旧市街の 中心市街に近く、また市民会館の集会室を市庁舎職員の会議室とし ても利用できるように市庁舎にも近い位置とする注 23 )。しかし、議 事録の内容によると、建設委員会は市民広場における市民会館と既 存の市庁舎、公会堂、望楼との関連性については言及していない。

\section{2. 丹下健三による初期計画案（1964 年 8 月 6 日〜1964 年 8 月} 30 日)

今治市は 1964 年 8 月 6 日、市庁舎建築群を設計した丹下健三に 市民会館の設計依頼を行う注 24 )。わずか 3 週間余り後の 1964 年 8 月 29 日、丹下健三は計画の概要と平面計画を図面にまとめた上で、 計画案を今治市に提出する注25)。
計画案において丹下健三は、予算と建設予定地を建設委員会の 計画に基づきながら、建設委員会の計画とは異なる 2 階建ての建

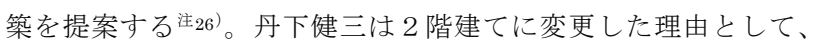
既存の市庁舎建築群との景観的な調和をはかること、敷地の地盤 が弱いこと、予算が不足することをあげている。また、脆弱な地 盤を理由に半地下の駐車場をやめ、地上の市民会館と市庁舎の間 に 5 台分の駐車場を設けている注27)

今治市は、丹下健三の計画案が 2 階建てであることに対し、集 会室の数と面積が減少していることを理由に反対する。また、市 の中心部に低層の建物を建てることへの不満も示し、丹下健三に 2 階建てから 3 階建てに計画案を変更寸ることを求める。しかし、 半地下の駐車場をやめることについては、今治市は予算の不足か ら了承している注 28 )。

丹下健三は今治市の要望をもとに修正を行い、平面計画を図面 にまとめた上で、翌日の 1964 年 8 月 30 日に修正案を今治市に提 出する ${ }^{\text {注 }} 29$ )。丹下健三は修正案において規模と平面計画を再検討 し、部分的に 3 階建てへ変更して大まかな平面計画を行う。

丹下健三は平面計画において、市民会館の入り口を市民広場に 向けて計画し、1 階の玄関ホールと 2 階のロビーを市民広場側に 配置している注30)。また市民広場においても、既存の舗装を市民 会館の入り口まで延長させている。

このように丹下健三は、市民会館と 3 つの建築物に囲われた広 場との連続性を重要視した計画を行っていると推論される。

丹下健三の修正案に対して今治市は、利便性から各会議室の面 積について再検討を行うことを条件としているが、概ね了承して いる 注 $_{31}$ ）。

\section{3. 丹下健三による最終計画案（1964 年 8 月 30 日〜1965 年 10 月 14 日)}

今治市は修正案をもとに施工図の作成を行うことを決定し、丹 下健三は施工図の作成のための最終計画案を作成する。最終計画 案では、今治市の要望に即して各会議室の面積を再検討と会議室 の配置の変更を行った上で、立面計画を作成している。

会議室の配置変更により、和室会議室が 2 階から 3 階に変更さ れている。その際、和室会議室では縁側を市民広場だけに設ける ことで、修正案よりも市民会館と市民広場との眺望としての関連 性が強くなっている (図 4)。

さらに、旧市街と市民広場を結ぶ前面道路の延長線上に外部階 段を設け、外部階段の踊り場から前面道路を通して旧市街に視線 が抜けるように計画している。

立面計画では、市民広場に面する西側の壁面については、1 階 の壁面をガラス面とし 2 階の壁面をガラス面とコンクリートのル ーバーにより構成することで、市民会館の内部から市民広場が眺 望できるように計画している。

また、丹下健三は、市民会館の計画に加え市民広場の整備計画 を行い、市民広場の全面舗装と、市庁舎の西に隣接する位置に駐 車場の整備を提案する。この整備によって、丹下健三は市庁舎と 公会堂、市民会館により囲われた広場の駐車場化を防ごうとして いると考えられる。

たしかに丹下健三は、最終計画案において外部階段や平面計画、 立面計画などにより以前よりも市民会館と市民広場の関連性を強 
く意識している。しかし、議事録の内容や丹下健三による言説から は、市民会館と新市街、望楼との関連性についての構想は見つから ず、旧市街と新市街を関連づける公会堂を中心とする市民広場の空 間構成についても言及されていない。言い換えれば、丹下健三は、 市民会館の建設において、中心としての公会堂よりも、市庁舎、公 会堂、そして市民会館によって形成される市民広場と旧市街との連 続性を重要視していると考えられる。

施工図は 10 月 14 日に完成し、市民会館は丹下健三の最終計画案 に即して実現している。しかし、市民広場の全面舗装は行われてお らず、駐車場の整備も行われていない。そのため、来客者は市民広 場に自由に駐車している注 32 )。
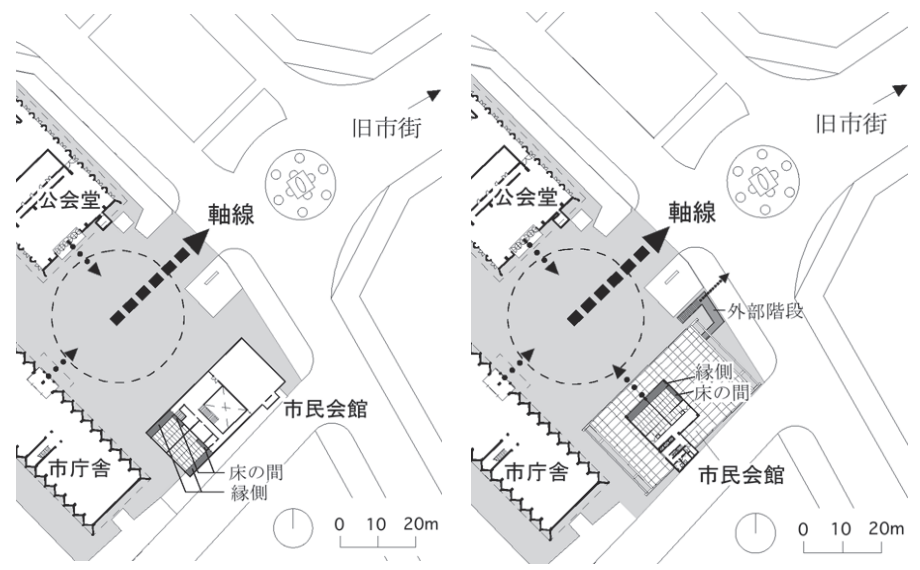

図 4 市民会館の初期計画案における 2 階平面図（左）と 最終計画案における 3 階平面図（右）注 33 )
4. 第 1 別館と第 2 別館の増築 (1970-1994）（表 2）

4.1. 今治市による第 1 別館の計画案（1970 年 5 月 25 日 1970 年 11 月 25 日)

今治市は、市庁舎の職員数の増加に伴う執務室の増築と、加え て水道局と衛生課、教育委員会事務局が市庁舎内に収容できず市 内に分散している状況を解消寸ることを目的として、1970 年 5 月 25 日に第 1 別館の建設を決定する。今治市は建設委員会を設 立し、建設委員会は他市庁舎の視察と今治市の現状をもとに検討 した第 1 別館の計画案を 1970 年 11 月に作成する。建設委員会は 計画案において、第 1 別館の規模、必要な設備、予算、建設予定 地の決定を行うが、平面計画と立面計画は行っていない。

建設委員会は、第 1 別館の規模を 5、6 階建てとし、建設予定 地を市庁舎の南西側に決定する。第 1 別館の建設予定地について は、市庁舎の計画当初より市庁舎西側を将来的な増築の予定地と して構想していたことから、当時の構想に基づき市庁舎の西側に 決定されたと推論される。

さらに第 1 別館の建設に伴い、市民広場の駐車場整備の必要性 が検討されるが結論は出ていない注34)。

\section{2. 丹下健三による第 1 別館の計画案 (1970 年 11 月 25 日〜} 1971 年 3 月 26 日)

今治市は、第 1 別館においても設計者として丹下健三を選出し、 丹下健三は今治市の構想をもとに作成した計画案を 1971 年 1 月 21 日に今治市に提出する ${ }^{3}{ }^{35)}$ 。丹下健三は計画案において、建設 委員会の計画案に即して規模と具体的な平面計画、立面計画をま とめている。

表 1 市民会館における計画案の変遷（1964-1965）注36)

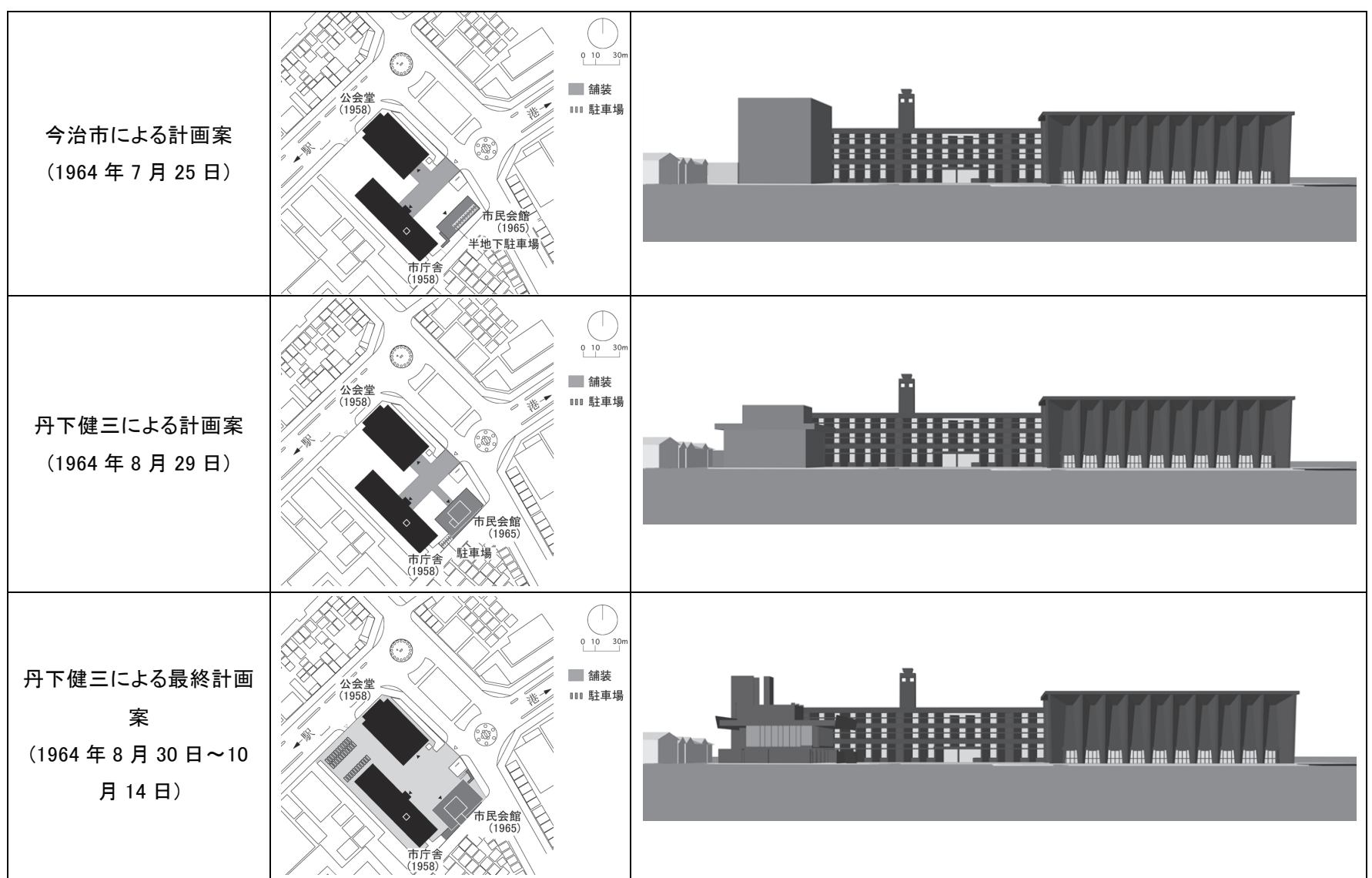


丹下健三は計画案において、今治市の基本構想より高層の建築を 提案する。今治市の基本構想が $5 、 6$ 階建てであるのに対し、丹下 健三は 10 階建てでかつ、屋上に 3 階建ての塔屋をもつ建築物を提 案している注 37 )

今治市は、この第 1 別館の高層化に対して、高層化しても建築面 積を抑えて延べ床面積が変更されていないことや、予算を今治市の 支払える額におさめているため了承している。

また、丹下健三は第 1 別館の屋上に設けられた塔屋に、展望室を 設けている。この展望室について今治市からの要望はなく、丹下健 三の提案により計画されたものである注38)。この展望室は旧市街と 新市街の両側へ向けられていることから、市庁舎屋上に設けられて いる望楼と同様の機能が、第 1 別館にも設けられている。

さらに、丹下健三は、第 1 別館の建設に伴い、市民広場の全面舗 装と、それに加えて第 1 別館の南側に駐車場を整備することを提案 する。来客者の利便性が高い市庁舎建築群の入り口が向いた旧市街 に開かれた市民広場ではなく、第 1 別館の南側だけを駐車場として 整備していることから、丹下健三は旧市街に開かれた市民広場の駐 車場化を防ごうとしていたと考えられる。

今治市は、概小丹下健三の計画を容認し、施工図の作成を決定す る。施工図面は 1971 年 3 月 26 日に完成し、宿直室の配置の変更が 行われているものの、丹下健三の計画案に即して竣工する。

しかし、駐車場の整備は第 1 別館南方だけ留まらず、市民広場全 体に及んでいる注39）。この市民広場の駐車場整備について丹下健三 による言説は議事録や作品集からは見つからず、この整備に丹下健 三が関与しているかは不明確であるが、少なくとも丹下健三自身が
異議を唱えた痕跡はない注40)。

\section{3. 丹下健三による第 2 別館の計画案（1992 年 5 月 29 日〜1994} 年 12 月 15 日)

今治市庁舎では職員の増加により再び職務空間の拡張が必要とな ったことから、今治市は 1992 年に今治市議会にて第 2 別館の建設 を決定する。同会議にて、今治市は建設委員会を設立し、建設委員 会は第 2 別館建設のための与条件をまとめた基本構想を作成する。

建設委員会は基本構想において、予算や施設に必要な機能と設備 の検討を行うが、第 2 別館の具体的な平面計画や立面計画、規模に 関する検討は丹下健三に依頼している。

建設委員会と丹下健三によりまとめられた計画案は 1992 年 5 月 29 日に作成され、同日に議会にて説明が行われる。丹下健三は、第 2 別館が第 1 別館と隣接することから概水第 1 別館と類似した形態 の平面計画を第 2 別館に採用しているが、第 1 別館よりも高層の建 築を提案する注 41 )。

しかし、第 1 別館より高層となる第 2 別館の最上部が二股に分け られたことで、第 1 別館の展望室からの新市街への眺望を確保され ている。そのため、第 2 別館の増築においても、第 1 別館から新市 街と旧市街を見渡す機能を維持されている。

また、丹下健三は、第 2 別館の東側と市庁舎の南側、第 1 別館と 公会堂の間、つまり市民広場の裏側に当たる場所を駐車場として整 備することを提案している。

今治市は、丹下健三の計画案を概ね了解し、施工図面の作成を決 定し、丹下健三の計画案に即して建設が行われている。しかし駐車 場の整備は、実際には今治市の庶務課が担当したため、丹下健三の

表 2 第 1 別館と第 2 別館における計画案の変遷過程 $\left.(1970-1994)^{\text {注 }}{ }_{42}\right)$

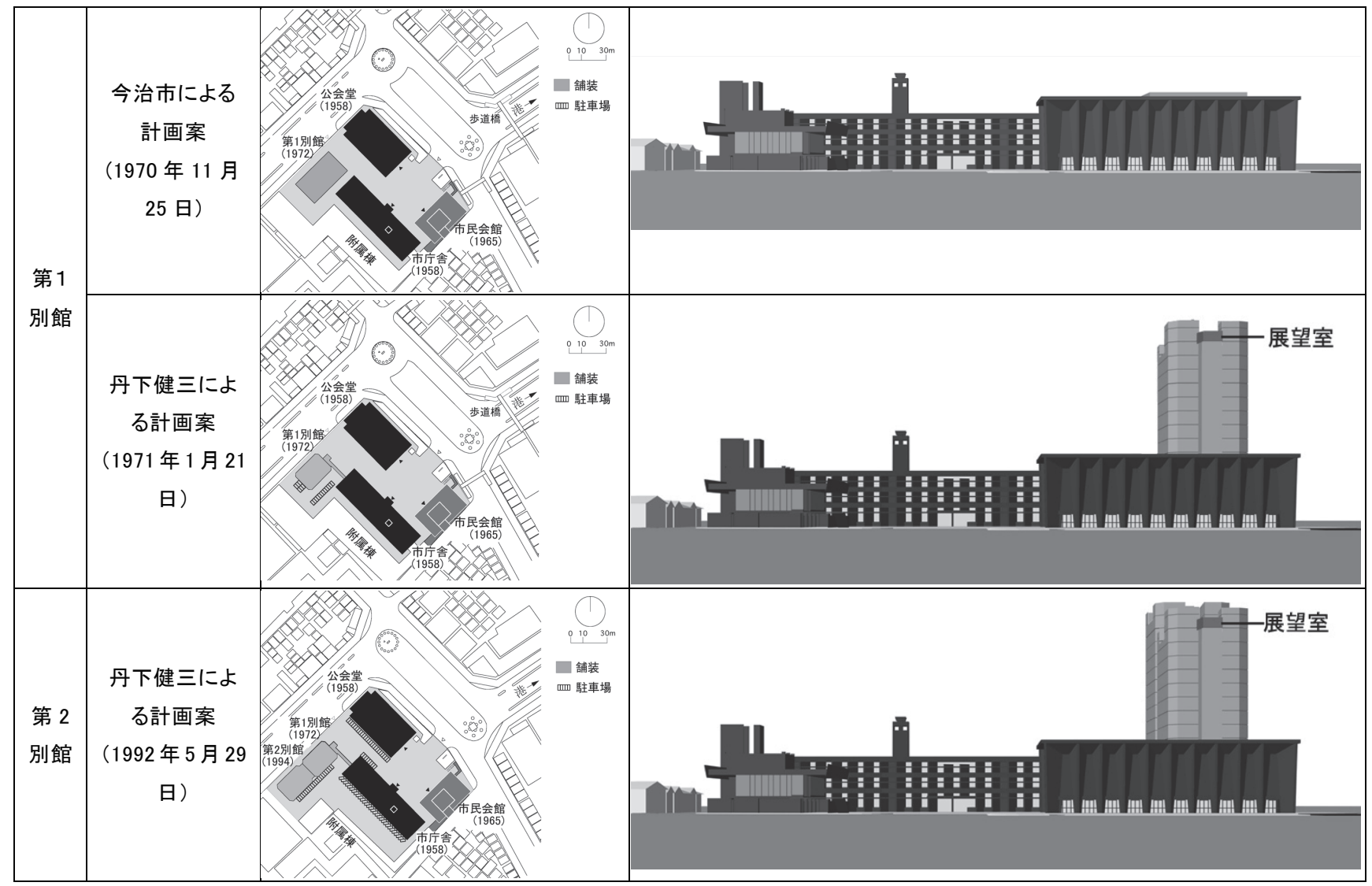


計画案とは異なり、市民広場全体が駐車場として整備される。

このように丹下健三は、第 1 別館と第 2 別館を高層の建築物とし て建設し、その高層部に展望室を設けることで、市庁舎屋上の望楼 が担っていた新市街と旧市街を眺望する機能を第 1 別館と第 2 別館 に引き継いでいる。そして丹下健三は、市民広場背後の駐車場の整 備によって、市庁舎と公会堂と市民会館に囲われた市民広場自体の
駐車場化を一貫して防ごうとし、市民会館増築事に強化された市民 広場と旧市街との連続性を維持しょうとしている。

5. おわりに（表 3）（表 4）

以上の丹下健三の市民広場における増築過程において、旧市街と 新市街を結びつける中心的なモニュメントとしての公会堂という考

表 3 増築過程における市民広場の変遷注 $\left.{ }^{43}\right)$

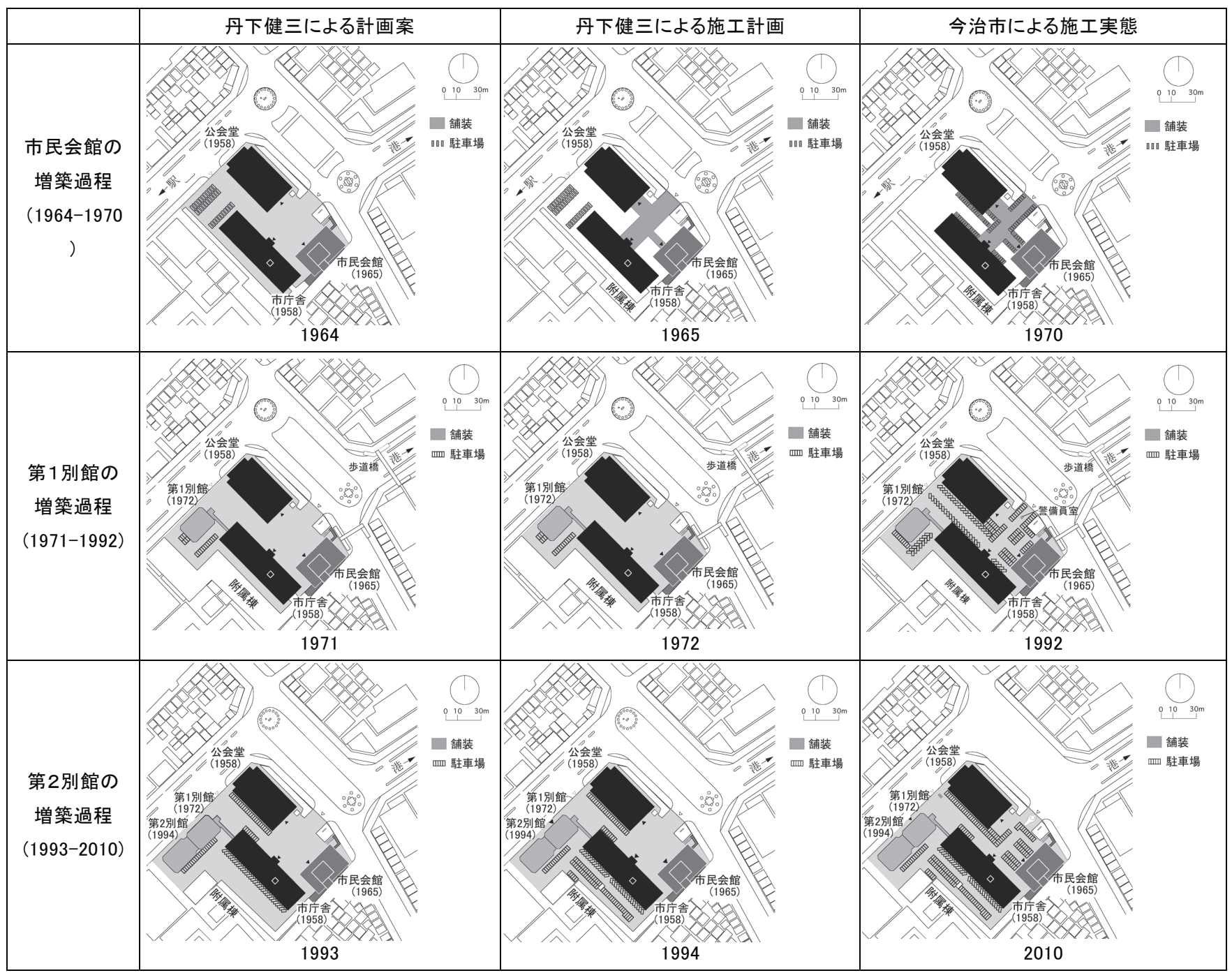

表 4 丹下健三における市民広場の空間構成の変化注 ${ }^{44}$ )

\begin{tabular}{|l|c|c|}
\hline 市宁舎、公会堂の建設 (1958) & 市民会館の增築(1965) & 第1別館及び第 2 別館の增築(1974-1994) \\
\hline 新市街 & & \\
\hline & &
\end{tabular}


え方よりも、公会堂、市庁舎、市民会館の三つの建築群から構成さ れる空隙としての市民広場という考え方に重点が移動していること は明らかである。丹下健三は増築過程において公会堂と新市街を関 係づける言説を残していないし、建築的な仕掛けも見出せない。む しろ、一貫して旧市街に開かれた市民広場の駐車場化を防ぎ、旧市 街一の軸線を強化する建築的な仕掛け（市民会館のヴォリューム構 成と市民広場の舗装）を強化している。

今治市の市民広場と市庁舎建築群に見られるような軸線を用いた 丹下健三の市庁舎建築は、今治市の市民広場以前には見られない。 今治市以前に丹下健三が設計した市庁舎では、敷地が都市の主要な 機能を結ぶ道路から離れていたことや、周辺に都市の象徵的な対象 がなかったことから、市民広場において軸線で結ばれる都市空間を 提案することはなかった注45)。しかも今治市の場合は、平和記念公 園（1955）のような一軸上の空間構成によってモニュメンタリティ


な地区との関連性をもち、かつ都市計画的にも今後の発展に重要と 位置づけられる道路が通っていたことから、丹下健三は市民広場の 空間構成において伝統的な都市空間を重要な要素として扱うことが できたと考えることもできる。

しかしながら、市民広場から新市街との関連づけが全くなくなっ てしまったわけではない。第 1 別館の展望室が機能不全を起こして いた市庁舎の望楼に代わって新市街を結びつけている。公会堂が直 ちにモニュメント性を失ったとは言い難いが注 47 )、新市街と旧市街 を結びつけているものが、旧市街から見れば公会堂の背後に建築的


いない。ここに、丹下健三の広場における壮大な視覚的モニュメン トの表現への強い志向性が認められる注 48 )。市民広場の増築過程で 明らかになったことは、伝統的な都市構造との関連の強化であるが、 結果的に、高さを求める視覚的なモニュメント表現が、眺望以外の 空隙としての市民広場から新市街地を排除したことである。

\section{注}

注1）土居義岳によれば、日本において「広場」という言葉が用いられたのは、 羽仁五郎による『都市』が最初であり（羽仁五郎、『都市』、岩波書店、1949）、 後に市民という意味を強調するために「市民広場」という言葉が徐々に普 及したと考えられる（土居義岳、『言葉と建築-建築批評の史的地平と諸概 念』、建築技術、1997、pp.291-313)。丹下健三が「市民広場」という言葉を はじめて用いるのは、今治市庁舎建設時、基本計画案作成時（1957 年 3 月） である。

注2）丹下健三の建築作品について、東京計画 1960（1960）に代表されるよ う都市計画的な視点からの分析も行われている（藤森照信・丹下健三、『丹 下健三』、新建築社、2002)。さらに、都市計画的な視点から丹下健三の設 計活動を位置づける研究も行われている（豊川斎嚇、「丹下研究室における 「都市のコア」と「建築のコア」: 都市と建築の有機的総合」『日本建築学 会計画系論文集』、第 621 号、2000 年、pp.165-171 ; 苅谷哲朗、「丹下健三 の都市軸構想と階層構造法に関する考察-丹下健三の都市デザイン その $1 」 『$ 日本建築学会計画系論文集』、第 696 号、2014 年、pp.561-570)。丹下 健三の庁舎については、東京都庁舎（1992）に代表される建築の造形手法 と黄金比との関連の分析がある (荻谷哲朗、「東京都庁舎の立面の階層構造 法による黄金分割に関する考察』『日本建築学会計画系論文集』、第 612 号、 2007 年、pp.161-168)。そして、丹下健三の広場については、丹下健三の初 期の作品と理念における記念性との関連についての分析（Benoit Jacquet、 「丹下健三の思考におけるモニュメンタリティの原理-初期作品の建築的 言説に関する研究一」、京都大学学位論文、2006)、広場を視点場とした建築 作品の視覚的比例関係についての分析などがある（荻谷哲朗、「仰角による
短縮方に関する考察一丹下健三とプロポーションに関する研究 その1」『日 本建築学会計画系論文集』、第 579 号、2004 年、pp.147-154)。しかし、丹 下健三の市庁舎作品における広場の空間構成の生成過程を具体的に分析し た研究はない。

注3）千代章一郎・関谷航、「丹下健三による今治市における市民広場の空間 構成」、日本建築学会計画論文集、第 709 号、2015 年 3 月、pp.717-725 注4）藤森照信・丹下健三、『丹下健三』、新建築社、2002

注5）丹下健三・川添登、『技術と人間』、美術出版社、1968

注6）丹下健三、『建築と都市』、世界文化社、1975

注7）今治市議会、『今治市議会議事録』、1951-1958、今治市役所蔵

注8）市庁舎及び公会堂建設特別委員会、『市庁舎及び公会堂建設特別委員会 記録』、1958、今治市役所

注9）市民会館建設委員会、『市民会館建設委員会記録』、1964-1965、今治 市役所藏

注10）市庁舎別館建設特別委員会、『市庁舎別館建設特別委員会記録』、 1970-1972、今治市役所蔵

注11）丹下健三、「市民会館建設施工図」、1964、今治市役所蔵

注12）丹下健三、「今治市庁舎別館・消防庁舎・附属棟新築工事設計図」、1972、 今治市役所蔵

注13）丹下健三、「今治市庁舎第 2 別館新築工事設計図」、1994、今治市役所 藏

注14）東豫時報社、『東豫時報』、東豫時報社、1956-1958、今治市立図書館 蔵

注15）今治市役所、『今治市誌 復刻版』、名著出版、1973

注16）今治市役所、『現代の今治』、今治市役所、1990

注17）今治市役所広報室、『今治市広報』、今治市役所、1958-1994、今治市 立図書館蔵

注18）著者撮影。

注19）丹下健三は市議会でこう発言する。「公会堂が廣場の中心にあり庁舎が その次にひかえており他市に見られないおもしろい構想であると思ひま す。公会堂の方が庁舎よりも高い考へです。将来周囲に高層建築が建っ た場合、その建物の最中に公会堂がたっておる。なかなかおもしろい構 想と思ひます。」(今治市庁舎及び公会堂建設委員会、『今治市庁舎及び公 会堂建設委員会』、今治市役所蔵)。但し、公会堂は市庁舎に比べて突出 した高さのあるヴォリュームというわけではなく、公会堂の中心性はあ くまで空間構成上の問題である。

注20）市長は、1964 年 1 月 28 日の市議会にて、市民会館建設の提案に加え、 自身の考える市民会館の構想について説明している。市長は、市民が集 会や結婚式に使用でき、市民の福祉促進を図る施設として市民会館を考 えている。建設予定地は、市庁舎からおよそ $50 \mathrm{~m}$ 南に位置する裁判所跡 とする。この時点で、具体的な平面計画や規模については構想されてい ない。そして後の議会で、建設予定地は市議会の議員から市民の利便性 や市役所の業務との関連性が良くないと言う理由から市民広場内に変更 されている。

注21）この計画案は今治市の建設委員会により作成されているが、この市民 会館建設のためには、とくに他市における市民会館の視察は行われてい ない (市民会館建設委員会、『今治市民会館建設計画書案』、1964 年 8 月 5 日、今治市役所蔵)。

注22）平面計画では、1 階に事務室や市民相談室、物産閲覧室など市庁舎の 機能に加え、市民談話室、新聞閲覧コーナーなどの市民の利用を目的と した機能が計画されている。そして、2、3 階には小中大の会議室を多数 計画し、4 階にはペントハウスが置かれる。これらは、それぞれ必要な 面積が計算され、具体的な配置計画も行われている。また、予算を 6000 万円としているが、この予算は当時の今治市の経済状況を踏まえた最大 の額としている。(市民会館建設委員会、『今治市民会館建設計画書案』、 1964 年 8 月 5 日、今治市役所蔵; 東豫時報社、『東豫時報』、1964 年 8 月 11 日、今治市立中央図書館蔵)

注23）東豫時報社、『東豫時報』、1964 年 2 月 1 日- 7 月 21 日、今治市立中央 図書館蔵

注24）今治市から丹下健三への設計依頼は、丹下健三も参加寸る今治市庁舎 で行われた会議中に直接行われた。その際今治市は、建設委員会の作成 した計画案についての説明と市民会館の建設に関する要望を丹下健三に 伝えている。市民会館の建設に関する要望とは、外観を市民が親しみや すく寸ること、内観に自然光を十分に取り入れて明るくすること、予算 範囲内におさめることである。丹下健三は、建設委員会による計画案に 対して、市民会館の建設により市民広場が狭くなることを懸念し、でき 
るだけ市民会館の建設予定地を東側に寄せること、それに伴い既存の公 衆便所を移動させることの許可、また建物だけでなく家具の設計の許可 を求めている(市民会館建設委員会、『今治市民会館建設計画書案』、1964 年 8 月 5 日、今治市役所蔵)。

注25）丹下健三・都市・建築設計研究所での主担当は、所長の神谷宏治 （1928 2014）と平賀国夫（1935～）である。国立室内総合競技場（1964） や東京カテドラル聖マリア大聖堂（1964）の竣工間際の時期であり、実 質的には神谷宏治が国立室内総合競技場と掛け持ちで市民会館の図面を とりまとめていたものと思われる。丹下健三は、自身に代わって神谷宏 治に計画案を持参させ、今治市に計画案を提出している。議事録には各 階に配置される機能と各室の面積、神谷宏治による発言が掲載されてい るだけであり、この計画案の説明に用いられた図面の所在と詳細は不明 である。また会議の内容は、当日中に今治市庁舎内の電話を使って神谷 宏治から丹下健三に説明され、その際の丹下健三の助言をもとに神谷宏 治が計画案の修正を行っている（市民会館建設委員会、『今治市民会館 建設計画書案』、1964 年 8 月 29 日、今治市役所蔵)。

注26）丹下健三は市民会館を 2 階建ての建築として計画し、1 階には物産展 示室、大中会議室、市民相談室、食堂、2 階には会議室、和室会議室、 談話室が計画され、今治市の構想に比べると会議室の面積が減少してい る。ただし、2 階建てとなる以前に、 5 階建てと 3 階建ての計画案も検討 した上で、利便性や敷地の条件、予算などを考慮し 2 階建ての建築を今 治市に提案している（市民会館建設委員会、『今治市民会館建設計画書 案』、1964 年 8 月 29 日、今治市役所蔵)。

注27）丹下健三の計画案において駐車台数は 5 台としているが、建設委員会 の計画案で予定されていた 10 台よりも減少している。丹下健三はこの後 に作成した計画案において市庁舎の東側に駐車場を設けていることから、 この時点でも同様に構想し、建設委員会の希望した台数の駐車は可能だ と考えていたと推測される。

注28）今治市は、半地下を設けることが予算の不足により難しいことは、建 設委員会による計画案の時点でも理解している。その上で、要望として 丹下健三に駐車場の設置を提案していた（市民会館建設委員会、『今治 市民会館建設計画書案』、1964 年 8 月 5 日、今治市役所蔵)。

注29）市民会館建設委員会、『市民会館建設委員会記録』、1964 年 8 月 30 日、今治市役所蔵

注30）丹下健三の平面図からは詳細が読み取れず、玄関ホールやロビーから の眺望などの市民広場との関連性については不明確である。

注31）今治市は、大会議室について、使用頻度が低くいことが予想でき、ま た大多数が集まれる集会所として既に公会堂を持っていたことから、大 会議室の面積をできるだけ狭くすることを求めている。また、和室会議 室についても同様に使用頻度が低いことが予想できることから、面積を 狭くすることを希望している。ただし、中会議室については、市庁舎内 の会議室が不足していたこともあり、できるだけ広く、また多くするこ とを求めている。そのため、丹下健三は修正案において、面接を狭くす るために和室会議室の配置を 2 階から 3 階に変更し、逆に中会議室を 3 階から 2 階に変更寸ることで今治市の要望に答えている（市民会館建設 委員会、『市民会館建設委員会記録』、1964 年 8 月 30 日、今治市役所 藏)。

注32）市民広場の周辺に大型の商業施設が複数建設されたことや商店街があ ったことから交通量が増加し、市庁舎前面のロータリーでは交通事故が 多発していた。そのため、今治市は 1968 年から 1970 年までの間にロー タリーの整備事業を行い、歩道橋を 3 カ所借設置する。また今治市の中 心市街で駐車場が不足していたことから、市民広場は附属寸る市庁舎や 公会堂の利用者だけでなく商業施設の利用者などにも駐車場として利用 された。今治市は、駐車場不足改善のために主要道の側道に駐車場を設 ける事や、商店街に駐車場をつくる事など検討している（森光繁、『今治 市制＼cjkstart五○年の思い出』、今治経済クラブ、p.124)。

注33）著者作成。建設委員会のよる会議の記録（市民会館建設委員会、『市 民会館建設委員会記録』、1964 年 8 月 30 日、今治市役所蔵）及び丹下 健三による作品集（丹下健三・川添登、『技術と人間』、美術出版社、 1968、p.76）をもとに復元を行う。

注34）建設委員会は、別館の建設に伴い車の最大駐車台数が減少することを 懸念し、建設する第 1 別館の地下に駐車場を設けることも検討している が、建設費の増加から断念する。代わりに、プレハブによる立体的な駐 車場を敷地内に設けることも構想されているが、具体化はされていない。 (今治市庁舎別館建設委員会、『今治市庁舎別館建設委員会記録』、1970 年 11 月 25 日、今治市役所藏)
注35）この時期丹下健三は、日本万国博覧会・基幹施設マスタープラン (1970) を作成しているため、その合間を見計らった計画案のとりまとめと思わ れる。やはり、市民会館を主担当していた神谷宏治を自身の代わりとし て今治市に計画案を提出している。そのため、丹下健三自身は会議に参 加していないが、神谷宏治の派遣は、今治市の市民広場における一連の 増築が一貫した構想であることを物語っている。

注36）著者作成。建設委員会のよる会議の記録（市民会館建設委員会、『市 民会館建設委員会記録』、1964 年 8 月 30 日、今治市役所蔵）及び丹下 健三による作品集（丹下健三・川添登、『技術と人間』、美術出版社、 1968、p.76）をもとに復元を行う。

注37）丹下健三は第 1 別館を今治市の 計画案よりも高層化した理由として、 将来的に別館の周辺に高層建築が建設される可能性があることから事前 に第 1 別館をそれらよりも高層にする必要があると説明しているが、将 来的な増床の必要性を訴えているわけではなく、論拠としては十分では ない（市庁舎別館建設特別委員会、『今治市庁舎別館建設計画の基本構 想とその経緯』、1 1970 年 11 月 25 日、今治市役所蔵)。立面計画におい ては、今治市からも既存の市庁舎と景観的に関連性を持たせて欲しいと いう希望があったが（市庁舎別館建設特別委員会、『今治市庁舎別館建 設計画の基本構想とその経緯』、1970 年 11 月 25 日、今治市役所蔵)、 当時、山梨文化会館（1966）がすでに竣工しコアシャフトに支持された 事務空間を応用したものとも考えられる。

注38）たしかにこの時期ですでに市庁舎の望楼は機能不全に陥っている（今 治市庁舎 財務部 管財課 職員への筆者によるインタビュー、2015 年 2 月 17 日)。図面より丹下健三が第 1 別館の屋上にある塔屋に展望台を設 けていることがわかるが、丹下健三は、第 1 別館に展望台を設けること についての説明を行っていない。なお、展望台に対する今治市からの賛 同や反対意見も見られない。

注39）駐車場の整備は第 1 別館の建設と平行して行われ、市民広場内には白 線や工作物、駐車場の管理を担当する警備員のための控え室が整備され る。それにより、第 1 別館竣工以降、今治市の市民広場は市民により駐 車場として利用されている。また今治市は市民広場の前面道路において、 事故防止のために 1975 年に整備事業を行い、ロータリーを一体型の形態 に改修する。

注40）後日出版された丹下健三の作品集において、全面が舗装された市民広 場と附属建築群の配置図が掲載されているが、駐車場として整備する計 画を丹下健三が構想していないことは明らかである。(丹下健三、『建築 と都市』、世界文化社、1975、pp.72-75)。

注41）丹下健三・都市建築設計研究所における第 2 別館の主担当者は、今治 市議会議事録からは不明である。第 1 別館より 20 年余り時間が経過して いるが、東京都心庁舎（1991）の竣工後であり、香川県新庁舎 (2000) の構想開始時期とも重なっている。丹下健三は、第 2 別館を第 1 別館よ りも高層化した理由について説明していない。一般的には延べ床面積の 確保のためであろうが、市民広場側の旧市街から見た造形的な調和のた めかもしれない。いずれにしても、当時丹下健三は増床の問題を高層化 によって解決せざるを得ない数多くの案件を抱えていたことになる。

注42）著者作成。建設委員会の上る会議の記録 (市庁舎別館建設特別委員会、 『市庁舎別館建設特別委員会記録』、1970-1972、今治市役所蔵及び総務 調整部、『今治市庁舎整備計画書』、1992-1994、今治市役所蔵）と丹下 健三による作品集 (丹下健三、『建築と都市』、世界文化社、1975、pp.72-75) をもとに復元を行う。

注43）著者作成。丹下健三による計画案については今治市に保管されている 建設委員会の議事録及び丹下健三による作品集から復元を行う（市民会 館には、丹下健三・川添登、『技術と人間』、美術出版社、1968、p.76 を参考にした。第 1 別館については丹下健三、『建築と都市』、世界文化 社、1975、pp.72-75 を、第 2 別館の復元には、総務調整部、『今治市庁 舎整備計画書』、1992-1994、今治市役所蔵を用いた)。丹下健三による 施工計画については、施工図を用いて復元を行う (市民会館には、丹下 健三、「市民会館建設施工図」、1964、今治市役所蔵を参考とし、第 1 別 館については丹下健三、「今治市庁舎別館・消防庁舎・附属棟新築工事設 計図」、1972、今治市役所蔵を、第 2 別館の復元には、丹下健三、「今治 市庁舎第 2 別館新築工事設計図」、1994、今治市役所藏を用いた。)。今 治市による施工実態については、郷土紙に掲載された写真を参考にして 復元を行った (今治郷土史編さん委員会、『写真が語る今治』、今治市役 所、1989、pp.269-293)。

注44）著者作成。

注45）そもそも市民広場の問題は東京都庁舎（1958）の構想において丹下健 
三に顕在化する主題であるが、その「シティ・ホール」あるいは「パブリ ック・スペース」は歩車道分離の観点からピロティによって押し上げられ、 建築的ヴォリュームの内側に引き込まれた空間であり、外部の都市空間 とは積極的な関連は見出されていない（丹下健三、『現実と創造 丹下健 三1946-1958』、美術出版社、1966、pp.158-159)。むしろ、戦後復興開発 の最中の無数に細分化された土地区画のなかで、建築的ヴォリュームの 内部に市民広場をつくろうとしている。

清水市庁舎（1954）については外部に広場があるが、丹下健三は市庁 舎の敷地が清水市の主要道から離れていることなどから、清水市庁舎と 都市との関連性が希薄なことを説明している(『建築文化』、彰国社、1955 年 3 月、pp.38-43)。倉吉市庁舎（1957）の場合、都市空間との関連性に ついて丹下健三による言説は見られないが、建設予定地が倉吉市の主要 道から離れたたところに建設されていることもあり、今治市ほどの都市 空間的な関連性についての構想は見受けられない。

今治市庁舎の次に設計された市庁舎である倉敷市庁舎（1960）では、 敷地の前面道路が倉敷駅にもつながり、また都市計画的にも重要な主要 道であったことから、市庁舎建築群と都市空間との関連性が主題化され ている。倉敷市においても市民広場が提案され、附属建築群で市民広場 の 3 方を囲い 1 方向で前面の道路に開くという空間構成となっている。 (『建築文化』、彰国社、1960 年 9 月、pp.28-42)。

注46）それはたとえば、広島平和記念カトリック聖堂計画（1948）の広場に おける非対称性の強い空間構成にも当てはまる。さらに丹下健三が市民 広場の原型としたストックホルムの市庁舎にも関連しよう（丹下健三、 『現実と創造』、前掲書、p.158)。さらに言えば、第 8 回 CIAM (1951) におけるル・コルビジェ（1887-1965）によるサン・ディエの都市計画 (1945) のピクチャレスクな空間構成に類似する（Eric Mumford, ”The New Monumentality”, The CIAM Discourse on Urbanism, 1928-1960,The MIT Press, 2000, pp.150-159 を参照)。丹下健三のル・コルビュジエへの直接的 な影響も否定できないが、今治の市民広場の場合、ル・コルビュジエが 仕掛けるピロティによる視線の抜けはなく、高層の第 1 別館と第 2 別館 がアイストップとして作用する。

注47）公会堂における視覚的モニュメンタリティの希薄化は 20 世紀における

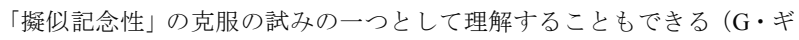
一ディオン、生田勉・樋口清訳、「新しい記念性の必要」、現代建築の発 展』、みすず書房、1961、pp.32-47)、ギーディオンが主催者の一人として 「都市の心臓」が議論された第 8 回 CIAM（1951）に出席した丹下健三 自身、そのことについては強く意識していたと思われる。

注48）たとえばそれは、広島平和記念カトリック聖堂計画（1948）の広場に おける鐘楼の突出にも認められる。それは後に、スコピエ都心部再建計 画（1965）をはじめとする都市計画的な広場において旧市街と関連づけ る対称性の強い囲い型の空間構成へと発展していく（『新建築』、新建築 社、1967 年 4 月、pp.109-143)。但し、今治市における市民広場の場合、 あくまで生成的な視覚的モニュメンタリティであり、国立室内総合競技 場（1964）のように、モニュメント建築物とそれを取り囲む都市の外部 空間としての広場という図と地の空間図式がはじめから明瞭に前提とさ れていたわけではない（丹下健三、『建築と都市デザインおぼえがき』、 彰国社、2011、pp.124-132)。丹下健三における都市軸のモニュメンタリ ティの系譜については、苅谷哲朗、「前掲論文」、2014 参照。 


\title{
THE TRANSFORMATION OF THE SPATIAL COMPOSITION ABOUT THE CIVIC PLAZA IN IMABARI CITY BY KENZO TANGE
}

\author{
Shoichiro SENDAI* and Wataru SEKIYA** \\ * Assoc. Prof., Graduate School of Engineering, Hiroshima Univ., Dr.Eng. \\ * Grad. Stud., Graduate School, Hiroshima Univ., M.Eng.
}

This paper aims to elucidate the transformation of the spatial composition of the civic plaza in Imabari city by Kenzo Tange through the analysis of the extension design process of the Imabari city complex. After the completion of the municipal buildings in Imabari city in 1958, the citizen hall (1965), the first annex (1972) and the second annex

(1994) were also built by Kenzo Tange in the civic plaza as the extension projects. So we analyze the design process of the civic plaza by Kenzo Tange in the extension projects.

First, this paper summarizes the spatial composition of the civic plaza in the completion of the municipal buildings in Imabari city in 1958 (Chapter 2). Secondly, in the extension projects, we analyze the design process by Kenzo Tange and the using condition of the civic plaza by the municipality. (Chapter 3 and 4). Finally, we elucidate Tanges' design on the civic plaza through the extension design process of the Imabari city complex (Chapter 5).

In the completion the municipal buildings in Imabari city, the civic plaza by Kenzo Tange has strong relation the traditional old area of the city by the belvedere on the top roof of the city hall and the pavement put on the extension of the front road. At the same time, Kenzo Tange disposes the civic auditorium as the monument of the center of the civic plaza connected with the old area and the new area.

By the extension project of the citizen hall, Kenzo Tange reinforces the arrangement of the Imabari city complex in the civic plaza. In its instead, the role of the civic auditorium as the center of the civic plaza is lost.

Next, in the completion of the first annex and the second annex, Kenzo Tange designs the annexes as the high-rise buildings which becomes eye-stop in Imabari city, and establishes the observation room in the top floor of the annexes like the former belvedere on the city hall.

In such the extension design process, Kenzo Tange connects the civic plaza in the urban structure of the Imabari city. However, the spatial composition of the civic plaza has changed. Kenzo Tange hands over the monumentality of the civic auditorium to the annexes as eye-stop and he removes the new urban area from to the civic plaza connected with the traditional urban structure. 